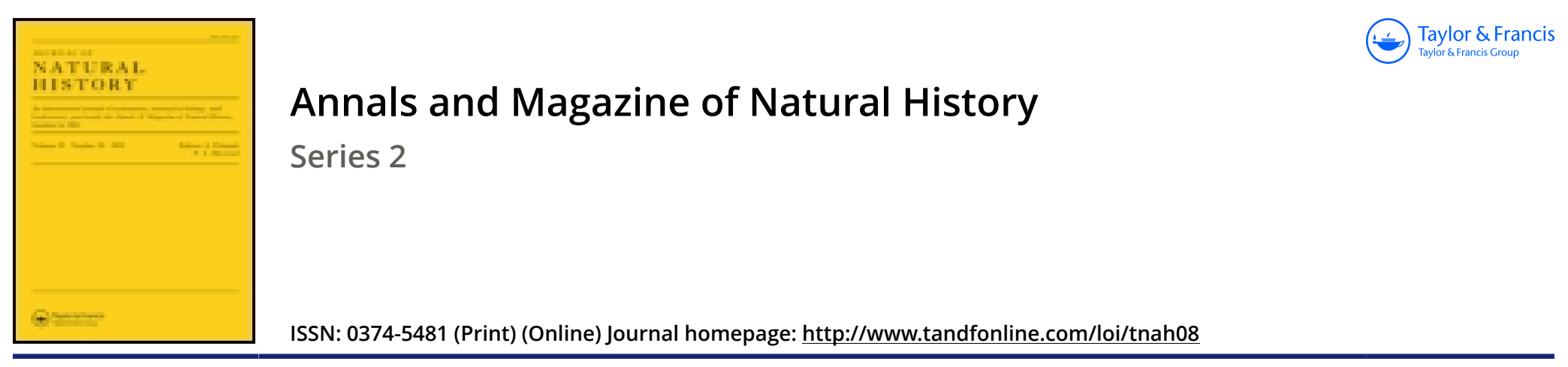

\title{
I.-On the conjugation of Cocconeis, Cymbella and Amphora; together with some remarks on Amphiphora alata(?), Kg.
}

\section{H.J. Carter Esq.}

To cite this article: H.J. Carter Esq. (1856) I.-On the conjugation of Cocconeis, Cymbella and Amphora; together with some remarks on Amphiphora alata(?), Kg., Annals and Magazine of Natural History, 17:97, 1-9, DOI: 10.1080/00222935608697461

To link to this article: http://dx.doi.org/10.1080/00222935608697461

曲 Published online: 26 Oct 2009.

Submit your article to this journal $\pi$

Џll Article views: 5

Q View related articles $₫$ 


\title{
THE A N N A L S
}

AND

\section{MAGAZINE OF NATURAL HISTORY.}

\author{
[SECOND SERIES.]
}

\author{
“. \\ per litora spargite muscum, \\ Naiades, et circum vitreos considité fontes : \\ Pollice virgineo teneros hic carpite flores : \\ Floribus et pictum, diva, replete canistrum. \\ At vos, o Nymphæ Craterides, ite sub undas; \\ Ite, recurvato variata corallia trunco \\ Veflite muscosis e rupibus, et mihi conchas \\ Ferte, Deæ pelagi, et pingui conchylia succo." \\ N. Parthenii Giannettasid Ecl, 1.
}

No. 97. JANUARY 1856.

I.-On the Conjugation of Cocconeis, Cymbella and Amphora; together with some Remarks on Amphiphora alata (?), $\mathrm{Kg}$. By H. J. Carter, Esq., Assistant Surgeon H.C.S., Bombay.

[With a Plate.]

THE discovery of the mode of reproduction in the Diatomeæ through spores, though inferred by Kützing, is really due to Mr. Thwaites. The former, seeing some of the cells in Meloseira dilated like those of $E$ dogonium, considered it sufficient to declare that this was one way in which the Diatomeæ were propagated*; but Mr. Thwaites recognized the process fully in Eunotia turgida in May $1847+$, and then first described and figured it most satisfactorily. He afterwards detected it in Fragilaria pectinalis, Gomphonema minutissimum, $G$. n. s. ?, Cocconema lanceolatum and Cistula, and in Epithemia gibba $\ddagger$; and subsequently in Meloseira varians and Borreri, Aulacoseira crenulata, Cyclotella? Kützingiana, Orthoseira Dickieii, Schizonema eximium, subco-

* Ap. Meneghini "On the Animal Nature of Diatomex," \&c., 1845. Eng. Trans. by C. Johnson, p. 369. Ray Society's Publications, 1853.

+ Ann. and Mag. Nat. Hist. vol. xx. p. 9. pl. 4.

† Idem, p. 343. pl. 22.

Ann. \& Mag. N. Hist. Ser. 2. Vol. xvii. 
Ann d Maq Nat Hist. S2. Vol 17 FL 1 .

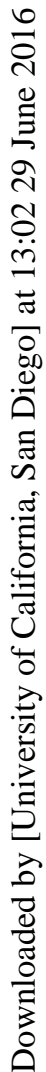
(2)

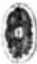
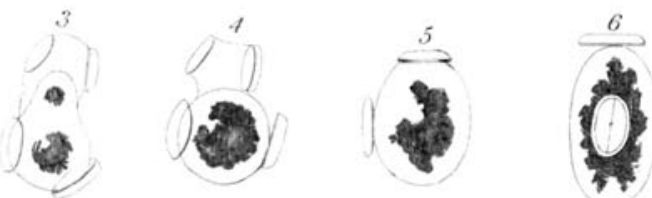
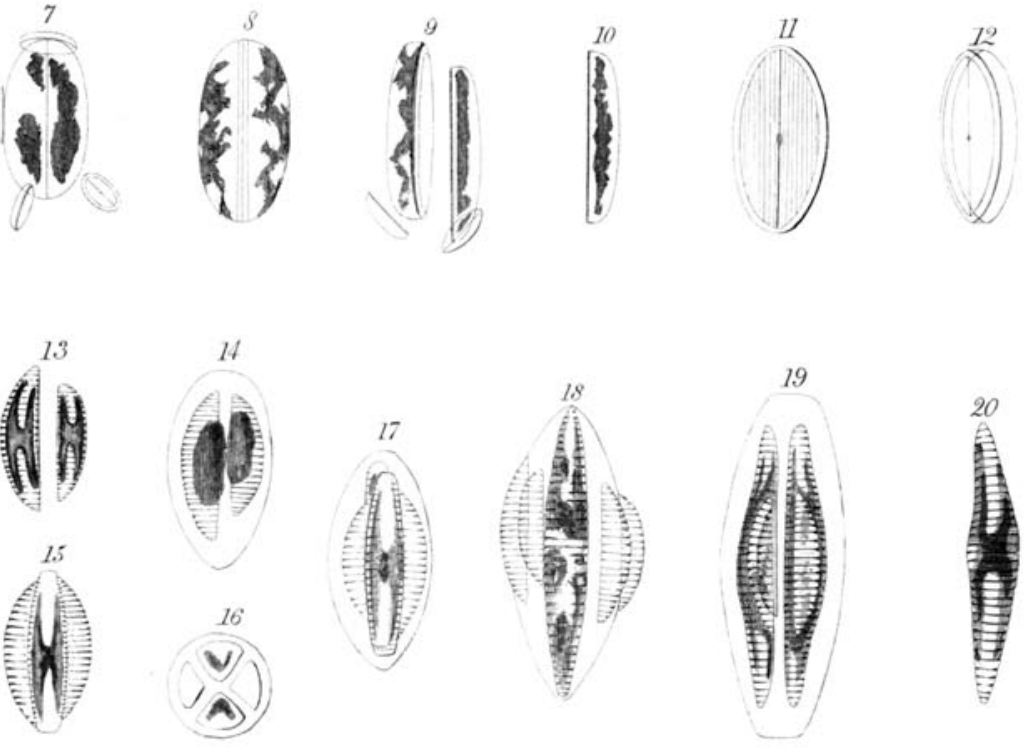

(1)

(a)
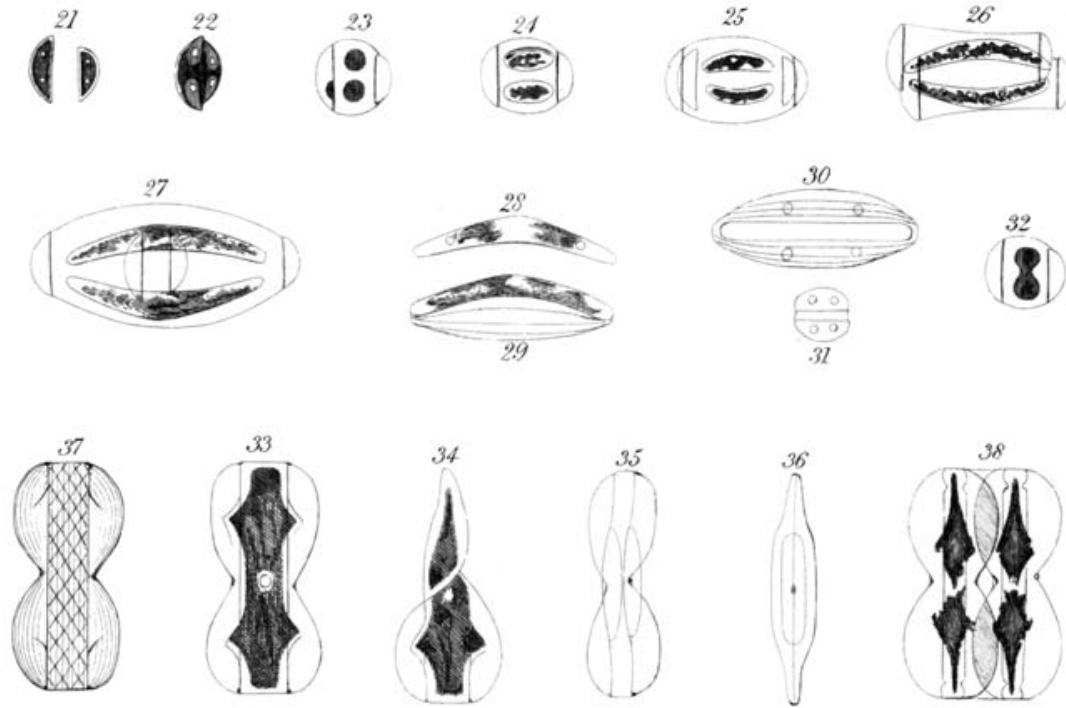
herens, vulgare and neglectum; and lastly in Dickieia Danseii*. Since that, no one seems to have added any more instances of this process of reproduction in the Diatomeæ, until Dr. J. W. Griffith noticed it in a species of "Navicula $\uparrow$;" and lately I have seen it in Cocconeis Pediculus (Kg.), Cymbella Pediculus (Kg.), and Amphora ovalis (Kg.), mihi, under such circumstances as to enable me to offer the following descriptions and figures of it respectively, in each of these genera.

Cocconeis Pediculus (Kg.). On the 4th of September, I perceived a brown incrustation extending over the sides of a basin in which Nitella, infested with Fragilaria and Cocconeis, had been kept for upwards of three months; and on examination with the microscope, it proved to be the latter, of different sizes, undergoing conjugation and deduplication.

The spore is formed by two of the smaller frustules, one of which is less in size than the other (Pl. I. fig. 1). These, after having become approximated, secrete a mucus which holds them together, while the lining mucus-membranes or primordial utricles respectively burst open the valves of their frustules (fig. 2), and approaching each other unite to form the spore (fig. 3); the latter then assumes a spherical form and the endochromes become mixed (fig. 4), after which the spherical form becomes elongated and finally elliptical (fig. 6) ; when, the endochrome also becoming scattered in more or less detached portions over the circumference, a single line appears, dividing the spore longitudinally into two somewhat unequal parts (fig. 7); two other lines then present themselves, one on each side the first (fig. 8); and the latter, passing into a groove, soon effects a deduplication of the spore, which then becomes divided into two sporangial frustules and thus the process is completed (fig. 9). Very soon after the spore has become spherical, the valves of the small conjugating frustule are thrown off, so that it is only now and then that they are seen ; while the valves of the large one remain attached to it until deduplication commences. The large conjugating frustule bears to the sporangial frustule (fig. 11) the proportion of $\frac{1}{1735}$ to $\frac{1}{57}$ of an inch; at least these are their respective measurements.

Cymbella Pediculus (Kg.). On the 17th of August, after having had a matted portion of Cladophora, Spirogyra and Oscillatoria together in a basin for a few days, a number of Cymbella of different sizes left the filaments and came to the sides of the vessel, where they conjugated.

* Ann. and Mag. Nat. Hist. vol. i. p. 161. pls. $11 \& 12,1848$.

+ Idem, vol. xvi. p. 92 . August 1855 . 
The spore is formed by two of the smaller frustules, one of which is less in size than the other (fig. 13). These, after having becorne approximated, first secrete around themselves a mucus in which they are thus imbedded. The commencement of the sporangial frustules is then indicated by two elliptical masses of endochrome appearing in the midst of this, parallel to and between the conjugating frustules (fig. 14); at least this is the earliest part of the process which I have observed. The sporangial frustules in which the endochromes are enclosed respectively, then become elongated (fig. 15); the transverse lines appear, the endochromes become scattered over their new habitations (fig. 17), and at length the frustules are formed (figs. 18, 19). By this time the mucus-investment and the valves of the conjugating frustules, which separate during the process, are thrown off, and the new frustules are thus liberated. The large conjugating frustule bears to the sporangial frustule (fig. 20) the proportion of $\frac{1}{5} \frac{1}{0}$ to $\frac{1}{3} \frac{1}{85}$ of an inch; at least, these are their respective measurements.

Amphora ovalis (Kg.), mihi. On the 31st of July, after a mass of that interesting form of Spirogyra, whose cells after division conjugate with each other, had spored and sunk to the bottom of the basin, with an Oscillatoria which was also present, several species of Diatomer multiplied upon the sides of the basin, among which were many frustules of Amphora of different sizes undergoing deduplication and conjugation.

The spore is formed by two of the smaller frustules, one of which is less in size than the other (fig. 21). These, after approximation (fig. 22), become invested in mucus, and, presently, exhibit their endochromes in two globular masses between them (fig. 23); elongation of the sporangial frustules which enclose these respectively takes place, transversely to the long diameter of the conjugating frustules (fig..24); the former then assume a bent form towards each other, and the endochromes becoming irregularly scattered through them, they attain their utmost development (figs. 24-27). Meanwhile the valves of the conjugating frustules become separated, and two remain at the ends of the sporangial frustules, while the other two appear about their middle, one on each side (fig. 27). The mucus then becoming dissolved, the valves of the conjugating frustules are thrown off, and the sporangial frustules are thus set free. The large conjugating frustule bears to the sporangial frustule (fig. 28) the proportion of $\frac{1}{1733}$ to $\frac{1}{5} 50$ of an inch; at least, these are their respective measurements.

Observations.-Nothing can be more obvious in these processes, than that one point gained by the conjugating of the 
small frustules is the restoration of the largest size of the species ; but perhaps not the most important point. In what way the small frustules are produced I am ignorant. Braun states that the effect of cell-division in the Diatomeæ is to reduce the size of the frustules $*$. This is evident enough in the cells of the Spirogyra; and Meneghini has pointed out how it must be the case from the conico-truncate form of Cocconeis, where the plane of division is parallel to the base of the frustule $\dagger$. But Braun deduces his opinion from what occurs in Gloeocapsa, where "the size of the cells diminishes with the increasing magnitude of the family stock (phytodon $\ddagger$ )," that is to say, that the last generations of cells are smallest.

That quantity should be required for restoring the size of the species, would appear from what takes place in the form of Spirogyra already noticed, where the original cell, after having been divided into four equal parts, ends in reuniting the contents of each contiguous two of these to form two new spores. Still more striking is the conjugation of two filaments of another species, where the cells of one happen to be divided into only two, and those of the other into four parts each. Here, although the conjugation is commenced as usual by active tubulation, the latter proves abortive; for the protoplasm of the large cells soon withdraws itself from the tube, and wraps its contents up into an elliptical spore of the normal size of the species; while the contents of every other small cell in the opposite filament (the intervening ones not sporing at ail) also wrap themselves up into small globular spores respectively, but not without a strong attempt at first to mix with those of their opposite neighbour;-inasmuch as, in one instance, the tubulation of the small cell with the large one appeared to have been entirely formed by the former, whose contents had even passed a little way into the latter, but finding the spore formed in the large cell, were about to return to their own, or to remain where they were when $I$ saw them in this position.

The rationale of this would at first appear to be, that the contents of the large cell found themselves sufficient in quantity to form the proper-sized spore, - which is the normal process in Zygnema mirabile (Hass.) §, while those of the small cell in the other filament found themselves in the opposite condition, and after making an attempt to mix with their opposite neighbour withdrew themselves, from finding no response, into their own

* "Rejuvenescence in Nature." Eng. Trans., by A. Henfrey : Botan. and Phys. Memoirs, published by the Ray Society, 1853. Foot-note, p. 132.

$\dagger$ Loc. cit. p. 406 . $\quad$ + Loc. cit. Foot-note, p. 131 .

Hassall's British Freshwater Algæ, p. 156. pl. 25. 
cell, and there wrapped themselves up into a small globular form*.

Again, in the conjugations above described, one frustule is always smaller than the other, as if only a certain quantity of cell-contents were required to make up the portion necessary for the reproduction of the new sporangia; and this is commonly the case also in the conjugation of Spirogyra, viz. that oue cell is smaller than the other; while in Cladophora, the whole of the contents of a cell move towards one end of it, where they are condensed into the elliptical form of spore proper to this genus, without any cell-division or conjugation of separate compartments.

Hence it becomes questionable, whether the division of the cell has anything to do with the formation of the spore; while again it cannot be determined that the formation of the spore is the process ordained for the perpetuation of the species, until it be known in what this process essentially consists, or whether sporing is the only means of reproduction.

On comparing the spore-formations above mentioned with those described by Mr. Thwaites in the Diatomex, it will be observed, that Cocconeis agrees chiefly with Fragilaria pectinalis, whose single sporangium, developed from two small frustules, " is at first cylindrical, soon assumes a flattened, somewhat quadrangular form, and in many, but not in all cases, undergoes fissiparous division before it has put on the exact appearance of a frustule of the Fragilaria $\varphi^{\prime \prime}$

The processes again in Cymbella Pediculus and Amphora ovalis respectively, agree with those of Cocconema lanceolatum $\ddagger$ and Eunotia turgida $\S$. In the latter, the way in which the process commences is detailed by Mr. Thwaites, but nothing is said about it in the former; and although it is easy to conceive how the sporangial frustules in Amphora ovalis should be formed like those of Eunotia turgida, yet it is not so easy to conceive how the processes commence in Cocconema and Cymbella, where the sporangial frustules lie parallel with instead of across the conjugating ones; unless we assume that another act takes place, in which either the conjugating or the sporangial frustules turn round to obtain this position.

* Should these small spores develope a filament, the latter would probably be below the normal size of the species; though the original size might be gained by the whole of the contents of a single cell of this development, with or without those of the cell of another filament, passing into one new spore. In this way among the Zygnemaceæ, as well as among the Diatomer, species may be added to this family and subclass respectively which after all are mere varieties.

+ Loc. cit. vol, xx. p. 334 .

$\ddagger$ Loc. cit. vol. xx. pl. 22 C. fig. 3, \&c.

$\S$ Idem, pl. 4. 
Now it so happens that in one of the earliest states that was presented to me of the conjugation of Amphora, the endochromes were joined together in the form of the figure 8 (fig. 32), and I could not help coming to the conclusion that the endochromes of both frustules passed into one sporangium at first, instead of directly into two, as in Eunotia, and then became divided afterwards; or, that this was an accidental occurrence. If this is the normal process in both Cocconema and Amphora, then it is easy to conceive how the sporangial frustules become opposite each other in both instances, viz. by the division of the united endochromes taking place either parallel or transversely to the longitudinal axes of the conjugating frustules. We have something analogous to this in Meloseira and Aulacoseira, where the axis of elongation of the sporangium is parallel with the filament in the former, and at right angles to it in the latter; with the line of division of course the reverse in each $*$, that is, with the filament in Aulacoseira, and across it in Meloseira ; corresponding in the former to Amphora and in the latter to Cymbella. Facts however are wanting to prove this conjecture.

I need hardly call attention to the difference in the size and forms of the conjugating and sporangial frustules which are represented in the Plate, or again remind the reader of what Mr. Thwaites has stated, viz. that the sporangial frustules, though very different from the conjugating ones at first, eventually assume a form very similar to them; this is effected by fissiparation, and equally applies to the endochrome as to the frustule. It is well seen in figs. 23-31. The relative size of the forms represented in the Plate has been preserved as much as possible, and each figure is taken from nature, with the exception of No. 2, which to supply a deficient link has been constructed upon No. 3 and other observations.

\section{Amphiphora alata (?), Kg. Pl. L. fig. 33.}

There are at least two species of this genus abounding in the back-waters of the island of Bombay, and as they do not appear to have been studied much in their living state, and have constantly come under my observation, I propose offering the following remarks on that one, which, if not identical with, is very nearly allied to the $A$. alata of Kützing $\dagger$.

Frustule.-Oblong, truncate ; primary surfaces closely approximated, lateral surfaces produced laterally and so compressed as to form a thin edge, which, being constricted in the centre,

* Thwaites, loc. cit. vol. i. p. 161. pl. 11. A 2, B 2.

$\dagger$ Species Algarum, p. 93. I regret that $I$ have not his figures to determine this satisfactorily. 
represents two alate, hyaline appendages on each side, thus giving the frustule the form of an hour-glass flattened. Valves forming the primary surfaces thick, oblong, truncate, sometimes striated (plicated?) longitudinally, closely approximated throughout, suddenly compressed and narrowed at each end, supporting on their sides the alate appendages mentioned. Endochrome: flat, double lozenge-shaped, connected ; consisting of a single (?) layer, continuous, presenting a transparent area in the centre in which is the nucleus, and from which a few delicate branched threads radiate towards the sides of the frustule; chiefly confined to the central valves, but occasionally extending for a short distance into the hyaline appendages.

Movements.-Like those of Diatomeæ in general, but with a peculiar contortion, which brings one half of the frustule into right angles with the other. Deduplication, through the broad or primary surfaces. Size $\frac{1}{12} \frac{1}{2} 0$ to $\frac{1}{2} \frac{1}{7}$ of an inch long.

$H a b$. The brackish water in that part of the main drain of Bombay which mixes with the sea at every tide; abounding in silty clots of Oscillatoria which float on the surface.

Observations.-A clot containing several hundred specimens of this species was placed in a small wide-mouthed bottle in the middle of December, where they continued to deduplicate up to the middle of the following June, by the vessel having been replenished from time to time with fresh water. Long before the last of these frustules were seen the whole of the other organisms had perished, and the remaining contents of the bottle, which might have been supposed to contain a number of them empty, on being examined, were found to contain none; hence it may be inferred that the frustules are not siliceous or coherent. The most striking feature about this species is its contortion (fig. 34), which from the thinness and flexibility of the alate expansions is effected to such a degree, that the narrow lateral edges, respectively, in one half, are bronght almost into right angles with the primary or broad surface of the other; a phase which this Diatomean is continually assuming, and which, at first, is very difficult to understand. For some time I mistook it for an $\mathrm{Am}$ phora with one half of the frustule split open, and the edges turned back. The central valves are frequently marked with longitudinal lines (folds?), and fine lines may occasionally be seen cutting each other at acute angles across them; while a linear appearance also presents itself sometimes in the alate appendages parallel to their borders Fig. 37 shows all this; and sometimes their hyaline transparency is interrupted by white specks.

This species differs from the navicular forms in the general and greater flatness of its frustule, in the greater expansion of 
its alate appendages, and in the form of the endochrome, which, instead of being separated into two portions united through the intervention of the nucleus and its capsule, as in the navicular forms, and in Navicule generally, appears to consist of a single, continuous, thin layer like that of Cocconeis Pediculus. The lateral surfaces are not lanceolate ("anguste lanceolata"), as Kützing's description would seem to imply, and as they appear to be ; for when it is remembered that they are mere margins formed in the way mentioned, it is evident that this cannot be the case; but that it is the margins of the central valves which present the lanceolate figure (fig. 35), more particularly in the navicular forms; while in the species under description they are suddenly compressed at the extremities, and laterally present the form of a bottle at each end (fig. 36). Hence I am inclined to doubt the identity of this with Kützing's Amphiphora alata.

Besides the two bright-looking tubercles (holes*) at each extremity of the frustule which mark the union of the lateral edges with the corners of the central valves, there are two other tubercles or holes, one on each side in the angle of constriction (fig. 36), and therefore corresponding in position to the bole or mark in the centre of the lateral surfaces of the Naviculat.

Deduplication takes place through the centre of the flat surfaces, and the new individuals, besides remaining together until they are fully formed, sometimes separate before this takes place, and then present the wing-like appendages on one side only. In fig. 38, where deduplication is nearly completed, the central valves respectively will as a matter of course be found to be much narrower than the one represented in fig. 32, where deduplication has not yet commenced.

\section{EXPLANATION OF PLATE I.}

N.B. The black shade in all the figures is intended to represent the endochrome.

Fig. 1. Cocconeis Pediculus (Kg.). The two conjugating frustules relatively magnified. The largest $T_{7}^{\frac{1}{7} 3}$ of an inch long.

Fig. 2. Opening of the frustules and approximation of the primordial utricles with their contained endochromes. (Conjectural figure.)

Fig. 3. Union of the two utricles to form the sporangium.

Fig. 4. Spherical form of the sporangium.

Fig. 5. Elongation of ditto, and disappearance of the valves of the small frustule.

Fig. 6. Elliptical form of ditto, with the thin valve of the large frustule in front.

Fig. 7. Ditto, with the line of deduplication and the valves of both frustules still adherent.

* Kützing and Meneghini.

$†$ Meneghini, l. c. p. 422 . 
Fig. 8. The line of deduplication becoming sulcated and two other lines appearing one on each side.

Fig. 9. Deduplication effected.

Fig. 10. Lateral view of sporangial frustule.

Fig. 11. Inferior view of sporangial frustule without endochrome, $\frac{x^{\frac{1}{7}} 5}{\text { of }}$ an inch long.

Fig. 12. Oblique view of sporangial frustule after second or third deduplication. Lower individual.

Fig. 13. Cymbella Pediculus $(\mathrm{Kg}$.). Conjugating frustules relatively magnified. The largest $\frac{1}{6} \sigma$ of an inch long.

Fig. 14. Union of ditto in secreted mucus; endochromes elliptical, parallel with frustules.

Fig. 15. First appearance of sporangial frustules.

Fig. 16. Transverse section showing the relative position of conjugating and sporangial frustules at this period.

Fig. 17. More advanced stage.

Fig. 18. Ditto, where the valves of the conjugating frustules bave become divided. In this, as well as in figs. 15 \& 17, one sporangial frustule is hid behind the other, as explained by fig. 16 .

Fig. 19. Fully-formed sporangial frustules.

Fig. 20. Sporangial frustule after liberation from the sporangial mucus, \&c., $\frac{1}{385}$ of an inch long.

Fig. 21. Amphora ovalis (K $\mathrm{g}$.), mihi. Conjugating frustules relatively magnified. The larger $\frac{T}{i^{73} 3}$ of an inch long.

Fig. 22. Conjugating frustules approximated.

Fig. 23. Ditto disunited, but held together by mucus, in which is seen their endochrome divided into two spherical masses.

Fig. 24. Sporangial frustules appearing, and elongating transversely to the conjugating frustules.

Fig. 25. Ditto in a more advanced state, valves of conjugating frustules separating.

Fig. 26. Ditto with ditto, more separated.

Fig. 27. Sporangial frustules formed; two valves of the conjugating frustules remaining in the centre, and one at each end.

Fig. 28. Sporangial frustule liberated, $\frac{1}{6} \frac{1}{5}$ of an inch long.

Fig. 29. Ditto undergoing deduplication.

Fig. 30. Ditto after having undergone one or two deduplications, and again about to deduplicate.

Fig. 31. Conjugating frustule about to deduplicate; here inserted for comparison with fig. 30 .

Fig. 32. Supposed preliminary state to fig. 28 ; endochrome fissiparating.

Fig. 33. Amphiphora alata (?) (Kg.): shows the broad side of the frustule, the form of the central cavity, and the shape of the endochrome, with terminal and lateral foramina.

Fig. 34. Ditto under contortion.

Fig. 35. Oblique view without the endochrome, showing the two component parts of the frustule.

Fig. 36. Lateral view without endochrome, showing lateral aperture.

Fig. 37. Different forms of lineolation occasionally seen on the surface.

Fig. 38. Deduplication; complete separation of the individuals not effected. 